\title{
Pelaksanaan Pengawasan Keimigrasian terhadap Warga Negara Asing yang Menggunakan Visa Kunjungan Wisata
}

\author{
Fadli Saputra
}

Universitas Negeri Padang, Padang fadlisaputra360@gmail.com

\begin{abstract}
Padang City is a city located in the province of West Sumatra, with a very strategic geographical condition, making the city of Padang rich in natural beauty. The beauty of nature is used by people in Padang City as a tourist spot, so that it is able to steal the attention of foreign tourists to come to visit, foreign tourists who enter and leave the Padang City area, all of which are under immigration control. Immigration is a form of enforcement in the implementation of state government sovereignty, therefore to facilitate immigration in carrying out its duties and functions in the supervision sector of foreign visits, a class 1 Padang Immigration office was formed. Since the enactment of Presidential Regulation Number 21 of 2016 regarding Visit Visas in Indonesia, it is clear that 169 countries are free to visit Padang City only with their passports. The purpose of this Presidential Regulation is to increase foreign tourist visits to Padang City so that it has an impact on increasing national development in general and increasing economy in particular, foreign tourists who come are expected to have a positive impact on the economy of the people of Padang City. However, the fact is not as imagined by the Padang City Government, the tourist visit permit granted to foreign tourists is prone to abuse, especially looking for work or opening business land and settling in a place. Researchers took the research location at the Padang Class I Immigration Office, because the city of Padang is one of the most attractive cities to be visited by foreign tourists, especially its natural beauty. As a government effort in order to support the maintenance of stability, security and vigilance against all negative impacts arising from the crossing of people between countries, and the activities of foreigners in Padang City, it is deemed necessary to carry out supervision of foreigners and immigration actions in a fast, thorough, and coordinated manner, without must ignore the openness in providing services to foreigners who are at the Class 1 Padang Immigration Office.
\end{abstract}

Keywords: Implementation, supervision of foreigners, immigration

How to Cite: Fadli Saputra. 2021. Pelaksanaan Pengawasan Keimigrasian terhadap Warga Negara Asing yang Menggunakan Visa Kunjungan Wisata. Vol 5 (1): pp. 96-107. DOI: https://doi.org/10.24036/jess.v5i1

\section{Pendahuluan}

Kota Padang merupakan kota yang terletak di wilayah Provinsi Sumatera Barat, dengan kondisi geografis yang sangat strategis menjadikan Kota Padang kaya akan keindahan alamnya. Keindahan alam yang begitu besar dimanfaatkan oleh masyarakat yang ada di Kota Padang sebagai tempat wisata, sehingga mampu mencuri perhatian para wisatawan asing untuk datang berkunjung, Wisatawan yang datang berkunjung tidak hanya berasal dari dalam negeri tetapi juga luar negeri, 
wisatawan yang masuk dan keluar wilayah Kota Padang semua itu berada dalam pengawasan keimigrasian.

Peraturan Undang-Undang Nomor 6 tahun 2011 menyebutkan bahwa keimigrasian adalah bentuk wujud dari jalannya penegakkan dalam pelaksanaan kedaulatan pemerintahan negara, hal ini bertujuan untuk menjaga ketertiban bangsa dan negara sehingga dapat mencapai masyarakat yang sejahtera dan adil dengan berpegang teguh terhadap nilai-nilai yang terkandung dalam Pancasila dan juga Undang-undang Dasar tahun 1945. Keimigrasian memiliki fungsi untuk melakukan pelayanan baik masyarakat maupun orang asing yang dipekerjakan oleh pemerintahan guna untuk keamanan negara, penegakkan hukum dalam menunjang kesejahteraan masyarakat. Itu semua adalah peran penting yang dimiliki oleh keimigrasian dalam menjalankan sebagian dari fungsi dan tugas yang telah dilakukan oleh Penegakkan Hukum dan Hak Asasi Manusia di Negara Republik Indonesia, maka dari itu untuk memudahkan keimigrasian dalam menjalankan tugas dan fungsinya disektor pengawasan maka dibentuklah kantor Imigrasi di setiap wilayah.

Semenjak diberlakukannya Peraturan Presiden Nomor 21 tahun 2016 terkait Visa Kunjungan di Indonesia menjelaskan 169 Negara bebas melakukan kunjungan ke setiap wilayah Indonesia cukup dengan bermodalkan paspor, sabagai akibat dari peraturan tersebut terjadilah peningkatan wisatawan asing yang datang ke wilayah Kota Padang di setiap tahunnya yang terlihat di tabel 1.1

Tabel 1.1 Daftar Kunjungan Wisatawan Tahun 2019 KUNJUNGAN WISATAWAN TAHUN 2019

\begin{tabular}{|c|c|c|c|c|c|}
\hline \multicolumn{6}{|c|}{ KUNJUNGAN WISATAWAN TAHUN 2019} \\
\hline \multicolumn{6}{|c|}{ Kota Padang } \\
\hline \multirow[b]{2}{*}{ No } & \multirow[b]{2}{*}{ Tahun } & \multirow[b]{2}{*}{ Bulan } & \multicolumn{2}{|c|}{ Jumlah Kunjungan } & \multirow[b]{2}{*}{ Total } \\
\hline & & & $\begin{array}{l}\text { Wisatawan } \\
\text { Mancanegara }\end{array}$ & $\begin{array}{l}\text { Wisatawan } \\
\text { Nusantara }\end{array}$ & \\
\hline 1 & 2019 & Januari & 3,357 & 400,108 & 403,465 \\
\hline 2 & 2019 & Februari & 3,696 & 304,530 & 308,226 \\
\hline 3 & 2019 & Maret & 5,720 & 361,827 & 367,547 \\
\hline 4 & 2019 & April & 7,265 & 547,223 & 554,488 \\
\hline 5 & 2019 & Mei & 6,781 & 367,825 & 374,606 \\
\hline 6 & 2019 & Juni & 14,429 & 832,205 & 846,634 \\
\hline 7 & 2019 & Juli & 12,347 & 761,114 & 773,461 \\
\hline 8 & 2019 & Agustus & 6,524 & 345,613 & 352,137 \\
\hline 9 & 2019 & September & 4,766 & 240,776 & 245,542 \\
\hline 10 & 2019 & Oktober & 6,972 & 275,401 & 282,373 \\
\hline 11 & 2019 & Nopember & 7,624 & 379,126 & 386,750 \\
\hline 12 & 2019 & Desember & 8,870 & 568,488 & 577,358 \\
\hline \multicolumn{3}{|c|}{ Total } & 88,351 & $5,384,236$ & $5,472,587$ \\
\hline
\end{tabular}

Sumber: Dinas Pariwisata dan Kebudayaan Kota Padang

Berdasarkan Gambar 1.1 dapat dijelaskan bahwa jumlah wisatawan mancanegara dan wisatawan nusantara yang datang ke Kota Padang mengalami fluktuasi tahun 2019 seperti data pada gambar di atas. Peningkatan kunjungan dari tahun 2019 ini tidak lepas dari Peraturan Presiden No. 21 Tahun 2016 tentang Bebas Visa Kunjungan yang sudah diterapkan oleh Indonesia pada 3 Maret Tahun 2016 lalu untuk 169 Negara. Orang Asing penerima Visa Kunjungan dapat melakukan 
kegiatan untuk tujuan wisata, kunjungan keluarga, sosial, seni dan budaya, tugas pemerintahan, memberikan ceramah atau mengikuti seminar, mengikuti pameran internasional, mengikuti rapat yang diadakan dengan kantor pusat atau perwakilan di Indonesia dan untuk meneruskan perjalanan ke luar negeri.

Tujuan dari Peraturan Presiden tersebut untuk meningkatkan kunjungan wisatawan asing ke Indonesia sehingga berdampak pada peningkatan pembangunan nasional pada umumnya dan peningkatan perekonomian khususnya. Semenjak diberlakukannya kebijakan bebas visa kunjungan oleh Presiden RI Nomor 21 Tahun 2016 membuat wisatawan asing semakin meningkat masuk ke Indonesia. Oleh karena itu wisatawan asing yang datang diharapkan mampu memberikan dampak positif bagi perekonomian masyarakat Indonesia, karena pada dasarnya pemerintah hanya menerima Warga Negara Asing (WNA) yang memberikan manfaat kepada masyarakat dan Negara. Tetapi faktanya tidak seperti yang dibayangkan oleh pemerintah. Izin kunjungan wisata yang diberikan kepada orang asing rentan disalahgunakan oleh pihak yang tidak bertanggung jawab. Orang asing yang menyalahgunakan izin kunjungannya ke wilayah hukum Indonesia datang dengan modus berwisata lalu mereka mencari pekerjaan atau membuka lahan usaha dan menetap di suatu wilayah tertentu untuk keuntungan mereka pribadi. Peneliti mengambil lokasi penelitian di Kantor Imigrasi Kelas I Padang. Karena Kota Padang adalah salah satu Kota yang paling menarik untuk dikunjungi di Indonesia serta banyaknya destinasi wisata menjadikan Kota Padang dan beberapa tempat disekitarnya banyak dituju oleh para wisatawan yang bukan cuma berasal dari dalam Kota Padang tetapi luar Kota Padang bahkan luar negeri.

Pengawasan terhadap orang asing tidak hanya dilakukan pada saat mereka masuk, tetapi juga selama mereka berada di wilayah Indonesia. Maka dari itu dibentuklah Undang-Undang Nomor 6 Tahun 2011 tentang Keimigrasian. Dalam Undang-Undang ini disebutkanbahwa keimigrasian merupakan bagian dari perwujudan pelaksanaan penegakan kedaulatan atas wilayah Indonesia dalam rangka menjaga ketertiban kehidupan berbangsa dan bernegara menuju masyarakat yang adil dan makmur berdasarkan Pancasila dan Undang-Undang Dasar Negara Republik Indonesia Tahun 1945.

Sebagai upaya pemerintahan dalam rangka menunjang terpeliharanya stabilitas dan kepentingan nasional, keamanan, ketertiban umum, serta kewaspadaan terhadap segala dampak negatif yang timbul akibat perlintasan orang antar negara, dan kegiatan orang asing di wilayah negara Republik Indonesia dipandang perlu melaksanakan pengawasan terhadap orang asing dan tindakan keimigrasian secara cepat, tepat, teliti, serta terkoordinasi, tanpa harus mengabaikan keterbukaan dalam memberikan pelayanan bagi orang asing. Dari itu perlu bagi peneliti sebagai mengkaji lebih dalam mengenai pelaksanaan pengawasan keimigrasian di Kantor Imigrasi Kelas I Padang serta faktor yang mempengaruhi pelaksanaan pengawasan, untuk itu peneliti memaparkan hasil penelitian terkait tentang "Pelaksanaan Pengawasan Keimigrasian Terhadap Warga Negara Asing Yang Menggunakan Visa Kunjungan Wisata di Kota Padang”. 


\section{Tinjauan Kepustakaan}

\section{Pengawasan}

Dalam kamus besar bahasa Indonesia istilah pengawasan berasal dari kata awas yang artinya memperhatikan baik-baik, dalam arti melihat sesuatu dengan cermat dan seksama, tidak ada lagi kegiatan kecuali memberi laporan berdasarkan kenyataan yang sebenarnya dari apa yang ada di lapangan. Anwar (2011) mengatakan bahwa pengawasan adalah suatu tindakan yang dilakukan oleh aparatur pemerintahan guna untuk pelaksanaan tugas yang telah ditetapkan, dapat mencapai tujuan yang telah di rencanakan dan terhindar dari penyimpangan-penyimpangan yang telah terjadi. Simorangkir (2013) pengawasan adalah suatu proses yang telah ditetapkan sebelumnya di dalam penetapan pengukuran kinerja dan tindakan yang telah di ambil sebelumnya dapat dijadikan pendukung dari sebuah pencapaian hasil yang diinginkan sesuai dengan penetapan kinerja yang telah di tentukan.

Winardi (2000) menjelaskan bahwa pengawasan ialah suatu proses pelaksanaan baik semua yang dilakukan manajer atau pihak yang terkait didalam aktifitas, untuk tujuan melihat bagaimana hasil yang telah terlihat sesuai dengan hasil yang dilaksanakan.

Bani (2013) menjelaskan bahwa Pengawasan ialah suatu proses yang telah ditetapkan suatu perusahaan baik pekerjaan manajer melalui pelaksanaan, penyelenggaraan dan perencanaan sesuai dengan tujuan yang telah diperhatikan sebelumnya sesuai dengan kehendak yang diinginkan.

Mutakallim (2016) pengawasan adalah suatu langkah yang telah diatur di dalam sebuah penetapan untuk melihat kualitas awal kegiatan untuk mendesain ulang hasil yang telah didapatkan sebelumnya, sebagai pembanding antara kualitas yang nyata dengan langkah awal yang telah ditetapkan, untuk melihat apakah terjadi kesalahan-kesalahan, selanjutnya untuk memperbaiki dan memastikan kebutuhan pemerintahan atau perusahaan sudah mengambil dengan maksimal dengan mencapai target suatu kegiatan.

Jadi dapat dipahami bahwa pengawasan merupakan suatu usaha sistematik untuk menetapkan standar pelaksanaan tujuan dengan tujuan-tujuan perencanaan, merancang sistem informasi umpan balik, membandingkan kegiatan nyata dengan standar yang telah di tetapkan sebelumnya, menentukan dan mengukur penyimpangan-penyimpangan serta mengambil tindakan koreksi yang di perlukan.

\section{Tugas dan Fungsi Keimigrasian}

Kantor Imigrasi kelas I Padang mempunyai tugas melaksanakan sebagian tugas Direktorat Jendral Imigrasi di Wilayah Kota Padang sebagai berikut :

1. Kantor imigrasi kelas I Padang merupakan unit pelaksanaan teknis yang menjalankan fungsi keimigrasian di daerah Kabupaten atau Kota

2. Tempat pemeriksaan kantor imigrasi kelas I Padang merupakan tempat dilaksanakanya pemeriksaan yang berhubungan dengan keimigrasian di pelabuhan laut, bandar udara, pos lintas batas atau tempat lain sebagai tempat masuk dan keluar wilayah Kota Padang.

3. Kantor imigrasi kelas I Padang dan tempat pemeriksaan keimigrasian merupakan aset penting di suatu daerah yang mengingat bahwa keimigrasian 
merupakan pintu gerbang utama bagi orang asing yang akan melakukan kunjungan ke wilayah Kota Padang, maka dari itu penting untuk melakukan aset pelaksanaan pengembangan pengawasan yang baik dalam menjalankan fungsi keimigrasian pada suatu daerah.

\section{Warga Negara Asing}

Rifyan (2017) Warga Negara Asing merupakan seseorang yang menetap dan tinggal di suatu wilayah atau orang yang berasal dari luar negara lain, bukan berasal dari negara asal dan tidak secara resmi terdaftar sebagai warga negara yang di tempatkannya, tujuan orang asing tersebut ialah untuk semata waktu, baik itu kepentigan umum maupun kepentingan khusus. Berdasarkan UUD 1945 pasal 26 ayat (2) menyatakan bahwa Warga Negara Asing merupakan penduduk yang bertempat tinggal disuatu wilayah indonesia yang bukan berasal dari kewarganegaraan Indonesia. Sedangkan dalam UUD Nomor 3 Tahun 1946 pasal (13) mengatakan bahwa Warga Negara Asing merupakan penduduk yang telah tinggal dan kemudian menetap di wilayah Negara indonesia selama 1 tahun berturut-turut dan Warga Negara Asing telah diakui kedudukannya di Negara Indonesia.

\section{Visi}

Naoval et al. (2018) dalam ketentuan UU Republik Indonesia Nomor 9 Tahun 1992 terkait keimigrasian, yang disebutkan dalam pasal 6 ayat 1 mengatakan bahwa semua warga negara asing yang datang dan berkunjung ke wilayah Indonesia wajib menggunakan dokumen perjalanan yaitu visa. Sedangkan Peraturan pemerintahan No. 32 tahun 1994 tentang penggunaan visa yang menyatakan bahwa visa merupakan sebuah dokumen yang digunakan untuk izin masuk seseorang ke suatu negara yang dapat diperoleh dari keimigrasian atau kedutaan di negara orang asing tersebut untuk pergi ke negara- negara lainnya. kemudian visa juga merupakan cap atau tanda bukti untuk masuk ke suatu negara, boleh berkunjung ke suatu wilayah negara lain yang diberikan kepada orang asing ketika memasuki wilayah negara lain terutama wilayah indonesia yang kegunaannya untuk izin masuk.

Sadli (2019) berdasarkan Peraturan Pemerintah No. 32/1994, tentang visa, izin masuk dan izin keimigrasian, ada lima jenis visa:

a. Visa Diplomatik, diberikan kepada orang asing pemegang paspor diplomatik dan paspor lain untuk masuk wilayah Indonesia guna melaksanakan tugas yang bersifat diplomatik.

b. Visa Dinas, diberikan kepada orang asing pemegang paspor dinas dan paspor lain yang akan melakukan perjalanan ke wilayah Indonesia dalam rangka melaksanakan tugas resmi yang tidak bersifat diplomatik dari pemerintah asing yang bersangkutan atau organisasi internasional.

c. Visa Singgah, diberikan kepada orang asing untuk singgah di wilayah negara Republik Indonesia untuk meneruskan perjalanan ke negara lain atau kembali ke negara asal. Visa ini diberikan untuk singgah di wilayah negara republik indonesia paling lama 14 (empat belas) hari terhitung sejak tanggal diberikannya izin masuk di wilayah negara Republik Indonesia. 
d. Visa Kunjungan, sendiri diberikan kepada orang asing yang akan melakukan perjalanan ke wilayah Indonesia dalam rangka kunjungan tugas pemerintah, pendidikan, sosial budaya, pariwisata, bisnis, keluarga, jurnalistik atau singgah untuk meneruskan perjalanan ke negara lain.

e. Visa Tinggal Terbatas, sendiri terbagi menjadi dua jenis untuk melaksanakan kegiatan, yaitu untuk kegiatan dalam rangka bekerja dan tidak dalam rangka bekerja.

\section{Metode Penelitian}

Penelitian ini menggunakan metode deskriptif kualitatif yaitu penelitian yang berusaha menggambarkan/mendeskripsikan sebuah fenomena atau yang akan terjadi selanjudnya keterkaitan antara fenomena dengan kejadian yang akan dilihat dan diteliti dengan sistematis, nyata dan sesuai dengan apa yang diharapkan nantinya (Prabowo dan Heriyanto, 2013).

Dalam melakukan penelitian kualitatif, terdapat informan penelitian. Informan adalah orang yang dimanfaatkan untuk memberikan informasi tentang situasi dan kondisi latar penelitian. Informan merupakan orang yang berada pada lingkup penelitian, artinya orang yang dapat memberikan informasi tentang situasi dan kondisi latar penelitian. Untuk memperoleh data secara representative maka diperlukan informan yang memahami dan mempunyai kaitan dengan permasalahan yang sedang dikaji (Prasanti, 2018).

Jenis dan sumber data yang digunakan dalam penelitian merupakan data primer, yang dimana informasi yang penulis peroleh dari lapangan melalui wawancara langsung dengan kepala kantor, humas, dan karyawan yang ada di Kantor Imigrasi Kelas I Padang serta dengan Warga Negara Asing yang ada di kota padang, sehingga data yang dibutuhkan yang berkaitan dengan judul penelitian dirasa cukup. Data sekunder digunakan untuk mendukung data primer yang berasal dari bahan-bahan pustaka. Penelitian ini menggunakan data sekunder yang didapat dari sumber bacaan dan berbagai macam sumber lainya yang berupa artikel, hasilhasil studi, tesis, hasil survey dan sebagainya. Penelitian menggunakan data sekunder ini untuk memperkuat penemuan dan melengkapi informasi yang telah dikumpulkan melalui wawancara langsung dengan kepala kantor, humas serta Warga Negara Asing di Kota Padang. Selanjudnya sumber data untuk mendapatkan data yang diinginkan dalam kegiatan penelitian, peneliti memerlukan informasi yang jelas dan data-data akurat yang akan didapatkaan dari narasumber yaitu Kepala Imigrasi Kelas I Padang, Subbagian Inteligen Keimigrasian,Subbagian Tata Usaha Keimigrasian, Kepala Dinas Pariwisata dan Kebudayaan Kota Padang dan Warga Negara Asing yang terlibat dalam pelaksanaan pengawasan terhadap Warga Negara Asing yang menggunakan visa kunjungan wisata di Kota Padang. Teknik pengumpulan data yang di mana dintaranya wawancara terhadap narasumber baik dengan pertanyaan pendek maupun panjang secara langsung atau tatap muka. Yang terakhir dokumentasi yang dimana teknik yang digunakan secara langsung dengan mengambil data yang didapatkan dari narasumber dalam bentuk foto-foto, serta dokumen yang diperlukan untuk mendukung penelitiannya (Febriansyah, 2017). 
Adapun lokasi penelitian yang akan dilakukan di Kantor Imigrasi Kelas I Padang yang berlokasi di Jalan Khaib Sulaiman NO. 55 Belanti Padang Sumatera Barat Indonesia dari bulan Januari 2020-November 2020.

\section{Hasil dan Pembahasan}

\section{Pelaksanaan Pengawasan Keimigrasian terhadap WNA di Kota Padang}

Kantor Imigrasi mempunyai kewenangan di masing-masing wilayah terutama di wilayah Kota Padang, kantor imigrasi yang ada di Kota Padang mempunyai peran penting di dalam pengawasan terutama dalam seksi pelaksanaan pengawasan di lapangan dan imigrasi, di lapangan pihak keimigrasian diantaranya tim pengawasan orang asing dan di pihak imigrasi dibantu oleh bidang Intelijen dan penindakan keimigrasian. Di dalam keimigrasian terdapat kewenangan yang telah diatur sebelumnya pada peraturan menteri kehakiman dan hak asasi manusia (HAM) Nomor 19 tahun 2018 tentang bagaimana berorganisasi dan bagaimana proses yang dilakukan oleh pihak keimigrasian di dalam pengawasan (Keifer dan Effenberger, 1967).

Menurut Menteri Kehakiman dan Hak Asasi Manusia (HAM) terdapat pada pasal 19 menyatakan bahwa di dalam suatu bidang intelijen, penindakan keimigrasian dan tim pengawasan orang asing di wilayah Kota Padang mempunyai peran penting dalam pelaksanaan pengawasan yang baik terhadap orang asing di wilayah Kota Padang, diantaranya prosedur pengawasan yang telah diatur di dalam undang-undang diambil dan dijadikan patokan di dalam pelaksanaan pengawasan yang baik terhadap orang asing yang menggunakan visa kunjungan wisata di lapangan nanti dan kepada tim pengawasan orang asing dan pihak inteligen keimigrasian yang akan melakukan, penindakan keimigrasian dan bidang inteligen menyebutkan bahwa untuk pengawasan terhadap orang asing telah di lakukan ketika permohonan visa atau izin masuk ke indonesia, segala aktifitas yang di lakukan oleh orang asing di sekitar wilayah Kota Padang di pantau oleh pihak-pihak keimigrasian tersebut. terdapat empat variabel yang mempengaruhi suatu pengawasan diantaranya untuk menetapkan standar, sebagai pengukuran kerja, dalam proses membandingkan dan melakukan tindakan yang harus dilakukan (Muhlisa dan Roisah, 2020).

\section{a. Menetapkan Standar}

Mencari hasil yang diingikan atau menetapkan patokan yang akan dilakukan sebagai upaya untuk membandingkan atara hasil ketika telah dilaksanakan pekerjaan di dalam suatu wadah atau tempat. Standar merupakan pembatas antara apa yang akan dikerjakan di dalam pelaksanaan suatu kegiatan yang berlangsung untuk mencapai target atau sasaran yang akan dicapai (Mutakallim, 2016). Di dalam menetapkan standar atau patokan yang akan dilaksanaan pengembangan pengawasan yang baik terhadap orang asing yang menggunakan bebas visa kunjungan di kota padang secara menyeluruh dilakukan secara prosedur atau sudah ditentukan di dalam peraturan UU, yang di mana peraturannya tentang prosedur Keimigrasian pada undang-undang Republik Indonesia No 6 tahun 2011, diketahui bahwa pelaksanaan pengawasan keimigrasian telah terjadwal yang ditentukan 
dalam prosedur keimigrasian. Di dalam keimigrasian pihak tim pengawasan orang asing hanya melakukan pengawasan selama satu kali dalam satu bulan ke lapangan. Untuk menetapkan standar dalam mencapai target pelaksanaan pengembangan pengawasan yang baik terhadap orang asing yang menggunakan visa kunjungan wisata di wilayah kota padang yang dilaksanakan oleh pihak Inteligen dan Penindakan Keimigrasian masih belum efektif.

Hal ini dapat dibuktikan dengan sistem manajemen Keimigrasian Aplikasi Pelaporan Orang Asing (APOA) yang belum sepenuhnya maksimal. Sistem aplikasi pelaporan orang asing ini perlu dilakukan perbaikan agar dapat berjalan dengan baik dan sebagaimana yang diharapkan oleh Pemerintahan Kota Padang, kesalahan-kesalahan atau penghambat yang dilakukan oleh pihak Keimigrasian tersebut akibat dari kegagalan tim pelaksanaan pengawasan dan penindakan keimigrasian dalam melakukan pemantauan terhadap kegiatan yang dilakukan oleh orang asing di wilayah Kota Padang, maka untuk menghindari kesalahan-kesalahan dan penghambat yang terjadi perlu diadakan pengukuran kerja terhadap suatu pekerjaan yang dilakukan kembali dengan cara pelaksanaan pengembangan pengawasan yang terhadap orang asing yang menggunakan visa kunjungan di dilayah hukum imigrasi Kota Padang.

\section{b. Pengukuran kerja}

Mengadakan penilaian terhadap pekerjaan yang dilakukan dapat dikatakan sebagai bentuk dari hasil yang telah dilaksanakan oleh pihak tim pelaksana pengawasan dan penindakan keimigrasian, Inteligen dengan cara memantau seluruh kegiatan yang telah di lakukan dan melihat hasil yang telah di kerjakan sebelumnya (Mutakallim, 2016). Berdasarkan temuan peneliti, bahwa terkait dalam pengukuran kerja yang telah dilakukan oleh tim pengawasan orang asing dan penindakan keimigrasian bidang Inteligen telah melaksanakan tugas yang telah diberikan oleh pihak imigrasi di wilayah Kota Padang. Suatu bentuk pelaksanaan pengembangan pengawasan yang baik yang dilakukan oleh keimigrasian terhadap warga negara asing yang menggunakan visa kunjungan wisata, dilihat dari pengukuran kinerja sudah dapat dikatakan efektif. Hal ini dibuktikan dengan sudah adanya UU yang mengatur tentang prosedural pengawasan orang asing di negara dan pihak kantor imigrasi kelas I Padang sudah menjalankan aturan tersebut.

\section{c. Proses Membandingkan}

Bertujuan untuk perbandingan antara pengukuran dengan penetapan yang akan dilakukan atau aturan yang telah ditentukan sebelumnya gunanya untuk mengetahui di mana penyebab atau kesalahan-kesalahan yang akan ditemukan saat proses kerja (Mutakallim, 2016). Berdasarkan hasil penelitian, dalam hal membandingkan antara pelaksanaan dengan penetapan yang berlaku sudah berjalan efektif. Hal ini sesuai dengan yang telah dibahas oleh pihak inteligen dan penindakan keimigrasian mengatakan bahwa pelaksanaan pengawasan sudah sesuai dengan prosedur pengawasan keimigrasian dan sudah tercantum dalam RI No 6 Tahun 2011. 


\section{d. Melakukan Tindakan}

Tujuan dari pembetulan atau perbaikan atas kesalahan-kesalahan, yang telah terjadi sehingga aktifitas pelaksanaan berjalan dengan semestinya. Melaksanakan tujuan perbaikan ketika hasil dari data yang didapatkan menunjukkan hasil kesalahan,dapat dijadikan patokan untuk perbaikan, tindakan dapat diambil dalam berbagai macam misalnya di dalam patokan, standar harus diubah lagi, pelaksanaan harus diperbaiki dan keduanya harus dilakukan secara bersamaan (Mutakallim, 2016). Dalam melakukan tindakan di dalam pelaksanaan pengawasan yang telah dilakukan oleh keimigrasian terhadap orang asing yang menggunakan visa kunjungan wisata, bahwa pihak keimigrasian sudah menjalankan aturan sesuai dengan prosedural yang ada dan diatur dalam Undang-Undang Nomor 6 Tahun 2011.

Berdasarkan hasil pengamatan yang dilakukan penulis kepada para informan, maka penulis menyimpulkan bahwa tindakan yang harus dilakukan oleh kantor imigrasi kelas I Padang yang telah menangani 2 kasus tentang penyalahgunaan visa kunjungan wisata yang dilakukan oleh orang asing yang mana akibat kurang efektifnya pihak keimigrasian terhadap pelaksanaan pengawasan yang dilakukan diantaranya warga negara asing asal United State Of America (USA) dan Malaysia. WNA asal Amerika melanggar penyalahgunaan visa, dengan melakukan perdagangan obat herbal. Sementara warga Malaysia melakukan pelanggaran keimigrasian berupa visa kunjungan wisata yang sudah kadaluarsa atau berada di wilayah Indonesia melebihi masa tinggal. Bagi warga negara asing yang melanggar aturan akan dikenakan hukum, hukuman yang telah diatur oleh direktorat jendral, apabila orang asing tersebut melakukan pelanggaran yang berat akan dikenakan kurungan penjara selama lima tahun atau membayar denda sebesar 500 juta. Dengan dibuatnya laporan hasil pengawasan kinerja kantor imigrasi kelas I Padang pada tahun 2019 serta INTELDAKIM, TIM PORA dan Instansi terkait pelaksanaan pengawasan yang telah menyediakan data yang lengkap sebagai bahan hasil pengawasan. (Hasil pengamatan penulis selama melakukan penelitian di Kantor Imigrasi Kelas I Padang terhadap WNA yang menggunakan visa kunjungan wisata di Kota Padang).

\section{Faktor yang Mempengaruhi Pelaksanaan Pengawasan Keimigrasian terhadap WNA di Kota Padang}

Pelaksanaan pengawasan Keimigrasian yang telah dilakukan oleh kantor imigrasi kelas I Padang terhadap orang asing yang menggunakan visa kunjungan wisata di kota padang ialah salah satu bentuk cara yang harus di lakukan oleh pihak Kantor Imigrasi supaya orang asing tersebut terlihat atau terpantau keberadaannya di lapangan, Namun ketika dalam pelaksanaannya terdapat faktor yang mempengaruhi suatu pengawasan yang harus ditangani, diselesaikan maupun dicapai oleh pejabat Keimigrasian. Menurut Deshinta (2017) mendefinisikan sebagai suatu arahan yang dilakukan utuk mendekatkan pendekatan ke arah yang berfokus kepada kelancaran pelaksanaan untuk mencegah kesalahan-kesalahan dalam daya guna, hasil guna dan tempat guna pelaksanaan. Menurut Deshinta (2017) Mengelompokkan jenis faktor berdasarkan faktor administrasi dan faktor lapangan. 


\section{a. Faktor Administrasi}

Faktor Administrasi berasal dari dalam organisasi (Administrasi) baik kantor imigrasi maupun kantor yang mempunyai kerja sama dalam pelaksanaan pengawasan keimigrasian. Dalam pelaksanaan pengawasan keimigrasian terhadap orang asing yang menggunakan visa kunjungan wisata di wilayah hukum imigrasi Padang mempunyai faktor penghambat yang telah terlihat, dapat dikatakan berasal dari dalam keimigrasian. Dari hasil temuan penelitian bahwa faktor penghambat di dalam pelaksanaan pengawasan yang dilakukan oleh pihak keimigrasian Kota Padang yaitu sistem manajemen keimigrasian (APOA) Aplikasi Pelaporan Orang Asing yang belum sepenuhnya maksimal karena pihak keimigrasian belum sepenuhnya bekerja sama dengan pihak penginapan kecil. Keimigrasian hanya bekerja sama dengan pihak hotel besar, serta jika warga negara asing pergi ke tempat terpencil juga sulit untuk melakukan pemantauan karena faktor luasnya jangkauan kerja.

\section{b. Faktor Lapangan}

Faktor Lapangan ini berasal dari luar organisasi (lapangan) baik kantor imigrasi maupun kantor yang mempunyai kerja sama dalam pelaksanaan pengawasan yang telah dilakukan oleh pihak tim pengawasan orang asing inteligen dan penindakan keimigrasian. Dalam pelaksanaan pengawasan Keimigrasian terhadap orang asing yang menggunakan visa kunjungan wisata di wilayah hukum imigrasi Padang. Faktor penghambat yang telah terlihat dapat dikatakan berasal dari luar kantor imigrasi. Dalam hal ini dapat ketahui bahwa orang asing yang berada di wilayah Kota Padang untuk visa kunjungan berwisata tidak diperbolehkan bekerja oleh pemerintah Kota Padang, tetapi masih ada orang asing yang ketahuan bekerja pada saat berada di wilayah hukum imigrasi Padang atau di wilayah Kota Padang yang statusnya bebas visa kunjungan wisata.

Dari pembahasan yang telah dijelaskan dapat diketahui bahwa pelaksanaan pengawasan yang telah dilakukan oleh pihak keimigrasian terhadap orang asing yang menggunakan visa kunjungan wisata masih terdapat beberapa kekurangkekurangan, berupa warga negara asing yang seharusnya dapat memberikan kontribusi yang besar bagi wilayah Kota Padang tetapi malah sebaliknya, maka itu semua tidak sesuai dengan Peraturan Presiden RI Nomor 21 tahun 2016 yang berbunyi bahwa warga negara asing yang diperbolehkan masuk ke wilayah Indonesia adalah warga negara asing yang dapat memberikan dampak positif serta kontribusi yang besar bagi pembangunan pemerintahan maupun kesejahteraan masyarakat Indonesia. Dengan ditemukannya kesalahan yang terjadi di lapangan dan kesalahan yang dilakukan oleh orang asing, maka pihak Imigrasi dan Tim Pengawasan Orang Asing perlu untuk memperketat proses pelaksanaan pengawasannya, dengan mengoptimalkan sistem managemen pengawasan yang ada di setiap wilayah Kota Padang, supaya pihak Imigrasi dan Tim Pengawasan Orang Asing dapat mengetahui bagaimana kegiatan yang telah dilakukan oleh warga negara asing di lapangan atau di wilayah Kota Padang, hal ini dapat dilakukan dengan cara menetapkan standar, pengukuran kerja, proses membandingkan dan melakukan tindakan. 


\section{Penutup}

Berdasarkan hasil penelitian dan pembahasan yang telah penulis lakukan mengenai Pelaksanaan Pengawasan Keimigrasian Terhadap Warga Negara Asing Yang Menggunakan Visa Kunjungan Wisata Di Kantor Imigrasi Kelas I Padang, maka dapat penulis mengambil kesimpulan sebagai berikut:

1) Pelaksanaan Pengawasan Keimigrasian Yang Dilakukan Oleh Kantor Imigrasi Kelas I Padang Terhadap WNA Yang Menggunakan Visa Kunjungan Wisata Di Kota Padang. Yang terdiri dari variabel berikut:

a. Menetapkan Standar, tujuan dari standar adalah untuk mencapai target atau sasaran yang akan di capai oleh Keimigrasian terhadap pelaksanaan yang telah dilakukan selama pelaksanaan pengawasan WNA di Kota Padang.

b. Pengukuran kerja, Suatu penilaian atau koreksi pekerjan terhadap pelaksanaan yang telah dilakakukan oleh Keimigrasian selama WNA berada di Kota Padang

c. Proses Membandingkan, untuk mengetahui kesalahan-kesalahan yang terjadi pada saat proses kerja di lapangan terhadap WNA yang ada di Kota Padang .

d. Melakukan Tindakan, untuk memperbaiki kesalahan-kesalahan yang terjadi pada peroses pekerjaan Keimigrasian dan melakukan tindakan terhadap pelanggaran yang dilakukan oleh WNA di Kota Padang

2) Faktor yang mempengaruhi Pelaksanaan Oleh Kantor Imigrasi Kelas I Padang Dalam Pengembangan Pengawasan Yang Baik Terhadap WNA Yang Menggunakan Visa Kunjungan Wisata Di Kota Padang.

a. Faktor Administrasi, faktor yang mempengaruhi Keimigrasian terhadap pelaksanaan pengawasan WNA yang berada di dalam pengawasan Kantor Imigrasi Kelas 1 Padang.

b. Faktor Lapangan, faktor yang mempengaruhi pelaksanaan pengawasan terhap WNA yang ada di wilayah Kota Padang itu sendiri.

Dari kedua kesimpulan pelaksanaan pengawasan tersebut, semuanya berpengaruh terhadap efektivitas dan efisiensi pengawasan keimigrasian terhadap orang asing yang menggunakan visa kunjungan wisata di Kota Padang.

\section{DAFTAR KEPUSTAKAAN}

Anwar, Syaiful. 2011. Manajemen Sumber Daya Manusia. Bandung: Rosdakarya. Bani, Bromas. 2013. "Pengawasan Warga Negara Asing (Wna) Oleh Kantor Imigrasi Kelas Ii Tanjung Balai Karimun.” Journal of Chemical Information and Modeling 53(9):1689-99.

Deshinta, Wafia Silvi. 2017. "Fungsi Pengawasan Keimigrasian Dalam Pengendalian Radikalisme Pasca Penerapan Kebijakan Bebas Visa Kunjungan.” Jurnal Unnes 3(1):5-28.

Febriansyah, Angky. 2017. "Tinjauan Atas Proses Penyusunan Laporan Keuangan Pada Young Enterpreneur Academy Indonesia Bandung.” Jurnal Riset Akuntansi 8(2). doi: 10.34010/jra.v8i2.525.

Keifer, G., and F. Effenberger. 1967. "Pelaksanaan Pengawasan Warga Negara 
Asing Di Wilayah Kerja Kantor Imigrasi Kelas II Belawan Berdasarkan UU NO.6 Tahun 2011 Tentang Keimigrasian." Angewandte Chemie International Edition 6(11):951-52.

Muhlisa, Aisyah Nurannisa, and Kholis Roisah. 2020. "Penegakan Hukum

Keimigrasian Terhadap Penyalahgunaan Visa Izin Tinggal Kunjungan Lewat Batas Waktu (Overstay) Pada Warga Negara Asing." Jurnal Pembangunan Hukum Indonesia 2(2):145-57. doi: 10.14710/jphi.v2i2.145-147.

Mutakallim. 2016. "Pengawasan, Evaluasi Dan Umpan Balik Stratejik." Volume V, Nomor 2 V(Juli-Desember 2016):351-65.

Naoval, Pratama, Cardani Dhafasha, Program Studi, Hukum Keimigrasian, and Politeknik Imigrasi. 2018. "Upaya Penyelesaian Penyalahgunaan Bebas Visa Kunjungan Pada Warga Asing Dalam Menjaga Ketahanan Nasional ( Attempts to Solve Visa Free Abuse Visit to Foreigners In Maintaining National Resilience ).” (6):1-10.

Prabowo, Aan, and Heriyanto. 2013. "Analisis Pemanfaatan Buku Elektronik (EBook) Oleh Pemustaka Di Perpustakaan SMA Negeri 1 Semarang [Analysis of the Utilization of Electronic Books (E-Books) by Pemustaka at the SMA Negeri 1 Semarang Library].” Jurnal Ilmu Perpustakaan 2(2):1-9.

Prasanti, Ditha. 2018. "Penggunaan Media Komunikasi Bagi Remaja Perempuan Dalam Pencarian Informasi Kesehatan.” LONTAR: Jurnal Ilmu Komunikasi 6(1):13-21. doi: 10.30656/lontar.v6i1.645.

Rifyan, M. Andi. 2017. "Prosedur Pengawasan Orang Asing." 4(2):1-13.

Sadli, Muhammad. 2019. "Tinjauan Yuridis Terhadap Dampak Bebas Visa Turis Dikaitkan Dengan Maraknya Buruh Asing Illegal Di Indonesia." Skripsi Sarjana 1(Universitas Sumatera Utara):44.

Simorangkir, timbul aman. 2013. "Pnegawasan Keimigrasian Terhadap Orang Asing Oleh Kantor Imigrasi Kelas II Dumai Menurut Undang-Undang Nomor 6 Tahun 2011 Tetang Kimigrasian." Journal of Chemical Information and Modeling 53(9):1689-99.

Winardi. 2000. Langkah-Langkah Efektivitas Pengawasan. Edisi 12. Bandung: Tarsito. 